\title{
Effectiveness of Budgetary Controls on Budget Execution in Zanzibar
}

\author{
${ }^{1}$ Hawa Said Salum and ${ }^{2}$ Mamudu Daffay \\ ${ }^{1}$ President Office, Finance and Planning, Department for Budget \\ ${ }^{2}$ Dean, Faculty of Arts and Social Science
}

\begin{abstract}
This study aims at examining the effectiveness of budgetary controls on budget execution in Zanzibar. The proper linkages between public resources and its management through service delivery are the key to success of any government. The study adopted descriptive research design in which primary data was collected by the use of questionnaire. More over the study used a stepwise approach to generate model, where regression model was used to analyze the degree of the relationship between budgetary control and the extent to which it contribute to the performance of budget in Zanzibar. The results reveals that a budgetary control as perceived by various respondents is effective on the basis of planning and budgeting, monitoring and control, analyzing and feedback and thus concluded to have a positive relationship with budget performance. Based on the study, it is recommended that management should be ready to participate in budget execution process in order to remove the existing challenges.
\end{abstract}

Key wards: Budgetary Controls, Budget Execution, Budget Performance, Regression Model, Zanzibar.

\section{Introduction}

Undoubtedly in any nation budgets are part of national and management control instrument designed to promote efficient use of resources and providing support for other critical functions.

Budgets shows how Government entities plan for the spending of finite public resources. National budget serves as an important tool for resource mobilization, allocation, fiscal and economic management. It is an economic tool for facilitating and realizing the vision of government in a given fiscal year, and if a national budget is to serves as an effective tool in public sector, proper linkages and management of all the stages of budgeting is necessary.

Today, organizations use different procedures and techniques for controlling and planning functions. The most important one is budgeting, as it plays a significant role in planning and management of daily activities in many organizations. Many organizations consider budgetary control as the base for internal financial management which gives a wide management platform and lead to effective resource allocation. Organizations have been using budgetary control as it has contributed in maintaining the budget process and control the allocation of resources. With a minimum budget control, an organization can compare actual performance and budget and determine any differences followed by proper correction through budget control.

In recent years, much attention has been given to the strengthening of budget and planning and their interrelationship in developing countries including Tanzania. The advocacy of this has come from prominent international agencies as World Bank and International Monetary Fund. These agencies are all interested in encouraging developing and underdeveloped countries to improve their budget practice.

Similarly Zanzibar budgets therefore occupy a leading place among the special tools of management employed to direct and control the expenditures of government. As a good financial plan must have a financial control system for monitoring the situation, both to ensure that the plan is carried out properly and 
to facilitate rapid adjustments if economic and operating conditions change and require modifications to the plan. Zanzibar Government passes through different budgeting approaches time to time regarding the needs and effectiveness of service delivery. The budgeting approaches used include zero budgeting, rolling plan and forward budgeting, and line item budgeting. Due to different challenges faced line item budgeting, there arises the need to change into new budget approach called Program Based Budgeting (PBB).

Zanzibar shift to PBB budgeting in 2014/2015 in parallel with line item budgeting and continue to use that approach currently. Budget is prepared and executed in PBB basis so as enhance transparent and effectiveness of public services offered by MDAs.

\section{Problem statement}

RGoZ prepares its budgets annually and use them as the basis for guiding the expenditures in delivering services to the public. A proper allocation of resources and a clear mechanism of budgetary control is critical so as to achieve a desired objectives. Due to different challenges facing budgeting in Zanzibar has raised the need for Government to control its budget. Poor participation in budgetary process, low efforts in monitoring the budgets and poor quality in planning make MDAs fail to stick to the drawn budgets and thus resulted in failure to meet budgetary commitments. Also the existence of discrepancy between planned and budgeted activities and which are implemented during budget implementation make the process difficult.

Since the sole purpose of the Government is the provision of social services to the public a properly concerned budget may or may not leads to a goals because of problems involved in budgeting and budgetary control. The issue is does the Government implement the budgetary control system to their expectation? Do they work within the orders of their budgets in the day-to-day operation? Whether the Government budgeting system is a formality and reality or not? A clear budgetary control system is required in order to minimize budget variances and maximize efficiency.

By having a reliable budgetary control system the variation between the actual implementation and the budget results can be checked and corrective measures taken immediately. This arise the need to determine how budgetary control system effectiveness leads to performance of budget in Zanzibar.

\section{Theoretical reviews}

Two theories were used to govern this study. These are;

Allocation of Resource Theory: Allocation of resource theory was developed by Peteraf and Barney (2003). It is concerned with the discovery of how nations, corporate, entrepreneurs or individuals distribute financial resources through budgeting process to attain financial goals. The economic concept of resource allocation is an important area in any organization as described by invisible hand theory. Under invisible hand theory, the allocation of resources is done through competition, supply and demand by individuals and corporate. The needs for using a budgetary control system to allocate those scarce economic resources in government are very crucial. Government and Corporates distribute financial resources through budgeting in their attempts to meet predetermined financial targets. Therefore, this theory helps the Government of Zanzibar to allocate financial resources through budgetary control system to MDAs. The scarce resources available will be distributed to meet MDAs needs in the provision of social services to society depending on the plans and priorities of the Government.

Expenditure Theory: Expenditure theory was developed by Rubin (1990). This theory is of two kinds; the normative theory and the descriptive theory. Budgeting needs a normative theory in deciding its critical policy on financial expenditure. Normative theory explains why some corporate expenditure are given priority while others are not considered in their budgeting process, which in turn helps these corporates to perform well financially. This theory of budgeting accomplishment and acceptance means end of conflict over the government's role in society. In Zanzibar more resources are allocated to the highly priority sector such as health and education compared to others. 


\section{Empirical reviews}

This part of the study explains the reviews of relevant literature from various studies carried out by other scholars and writers regarding budgetary controls that contribute to understanding of budgetary control mechanism.

Karume Hasunga (2004), examine the influence of budgetary control on budget performance in LGAs Tanzania Mainland and choose Mtwara region as a case study. The findings indicate that budgetary controls were effective and adequate. On the other hand, the findings indicate that budget performance at LGAs in Mtwara region was perceived ineffective due to failure to receive all the funds budgeted for and some budget deviations influenced by political pressures. This implies that, the overall budget performance at LGAs in Mtwara region was not directly influenced by budgetary controls since the activities which received funds for execution were carried out as planned.

Marygoreth Lyaruu Joseph (2014) conducts assessment of budget and budgetary control in enhancing financial performance of an organization, the case study of TANESCO. The study findings revealed that budget and budgetary control contribute much to the effectiveness of the organization.

According to Joshi et al. (2003), examines budgetary planning, control and performance evaluation in developing countries. His findings revealed that most of the firms prepare long-range plans and operating budgets, and use budget variance to measure performance for timely recognition of problems and to improve the next period's budget. Moreover, findings showed that the main purposes of budgeting in most companies are to forecast, assist in profit maximization and control performance by investigating variances. Poor cooperation and ineffective planning are the main reasons for not achieving the required standard targets.

Although, the study of Nickson and Mears (2012) which aimed in assessing the role played by budgetary control to enhance financial performance of commercial banks in Boston Massachusetts, using a regression modal for analysis and the results revealed that budgetary control play a significant role to enhance performance of the banks.

In addition, the study of Silva \& Jayamaha (2012) evaluate the impact of budgetary process on organization performance was made and determine if there is a significant impact on performance in the industry. Based on the collected data from the financial statements, and using the correlation coefficients and analysis subjected that budgetary process have a positive association with organization performance in the industry. This proves that financial companies maintains all the procedures to control their budgets so as to ensure higher levels of performance and this brings a positive relationship between budgetary process and organization performance

\section{Research Methodology}

This part discusses research methodology which was employed in this study.

Research design: A cross-sectional research design was used in this study in which data is collected once across a population through sampling. A descriptive quantitative approach is used to establish the relationship between the independent variable (budgetary control) and the dependent variable (budget performance). Employing this research design has enabled the researcher to solve the issue at hand.

Study Population: The study population is 177 respondents as combination from Department of Budget, Accountant General Department and Department of fiscal and financial policies; however, it appears that only 57 employees are directly responsible for budgeting process.

Sampling design and sample size: The study use a stratified sampling in which the researcher subdivides the entire population into different subgroups. The research take a sample from three departments of Ministry of Finance and Planning which are Department of Budget, Accountant General Department and Department of fiscal and financial policies and then randomly selects the final subjects proportionally from the different strata. A total of 50 sample size selected using a stratified sampling technique. 
Method of data collection: Questionnaire was distributed to 50 respondents as sample size of this study. This tool was used because the researchers were able to manage the collection of information from a large number of people in a short period of time and in a relatively cost effective way. The respondents are given structured statements using a five-point Liker scale that are required to respond their views based on the rating of five points which are (1) Strongly Disagree, (2) Disagree, (3) Not Sure (4) Agree and (5) Strongly Agreed.

Data analysis: The researcher uses the Statistical Package for Social Sciences (SPSS) software to analyze data. Descriptive statistical techniques (such as; frequencies, mean, variances, and standard deviations) were used to analyse the collected data

\section{Research findings and Discussion \\ 6.1 Demographic Information}

Personnel characteristics of respondents have very significant role to play in expressing and giving the responses about the problem, keeping this in mind, in this study a set of personal characteristics namely, category of staff, gender, age, level education and working experience of the 50 respondents have been examined and presented in this chapter

Table 1 Demographic of the respondents

\begin{tabular}{|l|l|l|}
\hline Variable & Category & Percentage (\%) \\
\hline Category of staff & Other staff & 86.0 \\
& Head of division & 14.0 \\
& Male & 38 \\
Gender & Female & 62 \\
& & \\
Age & $18-29$ & 10.0 \\
& $30-39$ & 44.0 \\
& $40-49$ & 40.0 \\
& 50 and above & 6.0 \\
& & \\
Level of education & Certificate/diploma & 6.0 \\
& Bachelor Degree & 44.0 \\
& Master degree & 42.0 \\
& Above master & 8.0 \\
& & \\
Work experience & Below a year & 8.0 \\
& 1-5 years & 20.0 \\
& 6-10 years & 40.0 \\
& Above 10 years & 32.0 \\
\hline
\end{tabular}

The results revealed that $86 \%$ of the respondents were other staffs of departments. This indicate that many employees responsible for budgeting process are not heads of division and that they have low knowledge, opinions and technical skills concerning budgetary control issues as compared to heads of division. Also $62 \%$ of the respondents were female and this specified that budgetary control practices in Zanzibar is not gender based responsible. This is because the process involves more female compared to males and thus female employees are more practicing the budgetary control process compared to male.

Also most of the respondents (44\%) who understand the concept of budgetary control and its performance were around the age of 30-39 which is the normal working age of employee. This group of people is active, energetic and strong and hence is capable of participating in budgetary control and can manage to overcome the existing challenges of budgetary implementation process. 
Furthermore the results indicate that the majority of employees (94\%) are degree holders and that they are capable of handling the process, this provide more simplicity in the budgetary control process since they are well knowing the situation. Working experience is crucial in budgeting.

The results indicate that many employees (72\%) understand well the concept of planning and budgeting are those working between 6-10 years and above. This groups of working have more experience in budgeting so they can easy understand the issues related to budgetary control techniques.

\subsection{The Effectiveness of Budgetary Controls}

The aim of this study was to examine the effectiveness of budgetary controls in Zanzibar. This was done by analyzing the responses of the respondents (heads of departments and other staffs) on the statements about budgetary controls' effectiveness in the Ministry of finance and planning to see the extent to which they agree or disagree with the assertions. The aspects of the budgetary controls which were examined were Budgeting and Planning, Monitoring and Control, and Analyzing and Feedback. The findings and pertinent discussions are presented as follows

\section{a) Budgeting and Planning}

Table 2 below shows the descriptions of budgeting and planning results as perceived by different respondents of the study.

Table 2 Planning and budgeting results.

\begin{tabular}{|l|c|c|c|c|}
\hline & N & Mean & $\begin{array}{c}\text { Std. } \\
\text { Deviation }\end{array}$ & Variance \\
\hline $\begin{array}{l}\text { Programs and Plans are the basis for allocating } \\
\text { financial resources. }\end{array}$ & 50 & 4.3000 & 1.05463 & 1.112 \\
\hline $\begin{array}{l}\text { We normally identify highly-priority plans to } \\
\text { include in the budget. }\end{array}$ & 50 & 4.4800 & 0.81416 & 0.663 \\
\hline $\begin{array}{l}\text { Planning helps us to know the type and level of } \\
\text { resources to provide }\end{array}$ & 50 & 4.4400 & 0.90711 & 0.823 \\
\hline $\begin{array}{l}\text { Planning of the budget activities is done by the } \\
\text { departments. }\end{array}$ & 50 & 4.3600 & 0.85141 & 0.725 \\
\hline $\begin{array}{l}\text { Budget priorities are agreed upon the budget } \\
\text { dialogue }\end{array}$ & 50 & 4.5600 & 0.81215 & 0.660 \\
\hline Valid N (list wise) & 50 & & & \\
\hline
\end{tabular}

\section{Sources: researcher's findings}

The aspect of Planning and budgeting was analyzed by the researcher and the finding reveled that most of the respondents have strongly agreed that the budgetary control under the concept of budgeting and planning contribute on budget performance in Zanzibar. The results indicate that the average mean and standard deviation are very closer which indicate a closer relationship between the variables.

This finding is consistence with the findings of Karume (2004), who examine the influence of budgetary control on budget performance in LGAs Tanzania Mainland. The findings indicate that budgetary controls were effective and adequate due to good budget planning.

\section{b) Monitoring and control}

Also budgetary control influence budget performance through monitoring and control systems. The table 3 below gives a clear picture of monitoring and control as perceived by respondents of this study.

Table 3: Monitoring and control results

\begin{tabular}{|l|c|c|c|c|}
\hline & N & Mean & $\begin{array}{c}\text { Std. } \\
\text { Deviation }\end{array}$ & $\begin{array}{c}\text { Varian } \\
\text { ce }\end{array}$ \\
\hline Approved budget is communicated to stakeholders & 50 & 4.2200 & 1.14802 & 1.318 \\
\hline Funding MDAs is based on approved budget & 50 & 4.2600 & 0.96489 & 0.931 \\
\hline
\end{tabular}




\begin{tabular}{|l|c|c|c|c|}
\hline Adjustments I budget is done whenever necessary & 50 & 4.2400 & 0.95959 & 0.921 \\
\hline Budget performance is communicated & 50 & 4.0200 & 1.18649 & 1.408 \\
\hline Deviations from the approved budget are reported & 50 & 4.1000 & 1.16496 & 1.357 \\
\hline $\begin{array}{l}\text { Reasons for deviation from approved budget are } \\
\text { clearly identified }\end{array}$ & 50 & 4.8000 & 5.77115 & 33.306 \\
\hline There is clear tracking of programs results in MDAs & 50 & 3.7800 & 1.18304 & 1.400 \\
\hline Valid N (list wise) & 50 & & & \\
\hline
\end{tabular}

\section{Sources: researcher's findings}

The study reveals that most of the respondents agreed that monitoring and control influence budget performance since the average mean and standard deviation are very closer which indicate a closer relationship between the variables. Contrary the higher variation between the standard deviation and their mean indicate that some respondents have disagree upon the statement of the variables.

Moreover, this finding is related with the findings of Joshi et al. (2003), whose examines budgetary planning, control and performance evaluation in developing countries. Their findings revealed that most of the firms prepare long-range plans and operating budgets, and use budget variance to measure performance for timely recognition of problems and to improve the next period's budget. These firms perform well their budget because of their effective monitoring and control system in their organizations.

\section{c) Analyzing and feedback}

The study also interested to show how budget is analyzed and the feedback are shared among the stakeholders. Analysis is done by collecting the views of respondents concerning the matter. The results of the perception of respondents are presented in the below table.

Table 4: Analyzing and feedback results

\begin{tabular}{|l|c|c|c|c|}
\hline & N & Mean & $\begin{array}{c}\text { Std. } \\
\text { Deviation }\end{array}$ & Variance \\
\hline $\begin{array}{l}\text { Budget Performance reports are prepared } \\
\text { regularly }\end{array}$ & 50 & 4.2800 & 1.05056 & 1.104 \\
\hline $\begin{array}{l}\text { Management always take timely corrective } \\
\text { measures when adverse variations are } \\
\text { reported }\end{array}$ & 50 & 3.9600 & 1.12413 & 1.264 \\
\hline $\begin{array}{l}\text { Always there is a clear reporting of } \\
\text { programs results }\end{array}$ & 50 & 4.0800 & 1.10361 & 1.218 \\
\hline $\begin{array}{l}\text { Deviations from the expected and actual } \\
\text { reported results are common }\end{array}$ & 50 & 3.7400 & 1.25860 & 1.584 \\
\hline Our budget are always balance & 50 & 3.8000 & 1.30931 & 1.714 \\
\hline Valid N (list wise) & 50 & & & \\
\hline
\end{tabular}

\section{Sources: researcher's findings}

Most respondents have strongly agreed that analysis and feedback improve budget performance since many respondents have strongly agree the statement of the variables since the standard deviation are closer to the mean of the variables. This result evidences that analyzing and feedback influence budgetary control which also influence budget performance in Zanzibar.

Interesting, this finding agreed with the findings of Nickson and Mears (2012) which aimed in assessing the role played by budgetary control to enhance financial performance of commercial banks in Boston Massachusetts. Their results revealed that budgetary control play a significant role to enhance performance of the banks. In addition to these findings the author continued to say that if they played very well on their past experience of their budget, they probably work effectively. 


\section{Conclusion}

It is concluded in this study that budgetary controls during the budget execution in Zanzibar is perceived to be effective. However, this does not directly guarantee satisfactory budget performance. However, it is established that budget execution is ineffective and ineffectiveness does not emanate from poor budgetary controls, but it is a result of failure to receive all the funds budgeted for and deviations which are caused by orders from top management. Although the study concluded that there is a positive relationship between budgetary controls and budget performance in Zanzibar, this means that budgetary controls is not the only reason for high budget performance but existing of many other factors may affect the performance of budget in Zanzibar.

\section{Recommendations}

The recommendations of this study are based on the followings

Top management support: In order to have an effective budget execution process in Zanzibar there must be a support of top management. The management should be ready to participate in budget execution process in order to remove the existing challenges. Top executives must ensure that the budgeted activities are implemented as they planned and there are no off budgeted implementations of activities.

Stakeholder's participation in budgeting process: Since the findings indicate that budget participation has a significant impact on the budget performance hence the budgetary controls should not be top-down in nature, instead the top management should make efforts to elicit feedback from subordinates at different levels of organization. As such, top management needs to understand the positive impact of budgetary execution and participation of appropriate stakeholders involved during budget preparation.

The needs for timely disbursement of funds: Based on the findings, there is direct impact between funds disbursed to MDAs, timing for funds released and the activities implemented. The government should ensure that all MDAs are receiving funds on time in order to enable MDAs to carry out their activities and meet the targets of the planned budgets. Also the amount of funds released should be enough to carry out the planned activities.

Reducing off budget expenditures: In order to have effective budget performance in Zanzibar, the government should ensure the budget is executed as planned. This will occur if MDAs are real in their plans and plans are in line with their budgets. This will ensure effective implementation of activities based on their plans. In other hands, executives should not intervene with budget execution process and budget execution should be treated as independent activity which is free of any orders and pressures. The power of top managers should not be left to cause unnecessary deviations for the activities which were budgeted for.

Need for training and development: The study recommends that necessary training should be given to the key stakeholders involved during budget process including planners, accountants and budget officers on the importance of controlling the budget for better performance. In other hand, there is a need for top managers to identify the importance of budgetary control for the effectiveness of government operations.

\section{References}

1. Abdullahi, Y. S. (December 2011). Public budget and budgetary control in nigeria. Journal of Business and Organizational Development Volume 3, December 2011.

2. Anohene, J. (July 2011).Budgeting and budgetary control as management tools for enhancing financial management in local authorities, afigya kwabre district assembly as a case.

3. Hasunga, K. (2014 ). The influence of budgetary controls on budget performance in local government authorities (LGAs) in tanzania: a survey of LGAs in mtwara region .

4. Kaguri, K. F. (2015). The relationship between budgetary control and financial perfomance of insurance company in Kenya. 
5. Kimani, R. N. (October 2014). The effect of budgetary control on effctiveness of non govermental organizations in Kenya.

6. Maheshwari, D. (2006). Financial and Management accounting (5th ed). New Delhi: MDS Books.

7. mutungi, z. w. (november 2017). Effect of budgeting and budgetary control in financial perfomance of devolved government in Kenya.

8. Siyanbola, T. T. ( December 2013 ). The Impact Of Budgeting And Budgetary Control On The Performance Of Manufacturing Company In Nigeria. Journal of Business Management \& Social Sciences Research (JBM\&SSR) ISSN ,Volume 2, No.12, December 2013.

9. Joshi, J., \& Abdulla, M. (1996). Budgetary Control and Performance Evaluation Systems in Corporations in Bahrain, Asian Review of Accounting.

10. Waymire, T. R. (2007). An Examination of the Effects of Budgetary Control on Performance.

11. Waymire, T.R., \& Renea, T. (2007). An Examination of the Effects of Budgetary Control on Performance.

12. Silva, L. M. D., \& Jayamaha, A. (2012). Budgetary Process and organizational performance of Apparel Industry in Sri Lanka, Journal of Emerging Trends in Economics and Management 